EISSN: 2706-7955 ISSN: 2077-4605

DOI: $10.36632 /$ mejar/2021.10.2.42

Journal homepage: www.curresweb.com

Pages: 569-576

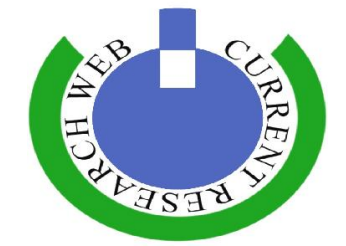

\title{
Effect of growth regulators on delay blooming and productivity of Almond trees
}

\author{
Amro S.M. Salama, Soraya A. Mohamed and Ahmed A.H. Hegazy
}

Plant Production Department, Desert Research Center, Cairo, Egypt

\author{
Received: 05 April $2021 \quad$ Accepted: 10 May $2021 \quad$ Published: 15 May 2021
}

\begin{abstract}
This study was carried out during two successive seasons of 2018 and 2019 in a private rain-fed almond orchard at Marsa Matrouh Governorate, Egypt. Nine years old almond trees cv. "Umm al-Fahm" grafted onto Bitter almond rootstock planted at a spacing $7 X 7 \mathrm{~m}$. to study the effect of naphthalene acetic acid (NAA) and salicylic acid (SA) treatments on delay blooming as well as their effects on vegetative growth and productivity. The experiment was performed in a randomized completely block design with four replications. Almond trees were subjected to five treatments as: control pure water, NAA as foliar sprays at $75 \mathrm{mg} \mathrm{l}^{-1}$, NAA as foliar sprays at $150 \mathrm{mgl}^{-1}$, salicylic acid as foliar sprays at $75 \mathrm{mg} \mathrm{l}^{-1}$, salicylic acid as foliar sprays at $150 \mathrm{mg} \mathrm{l}^{-1}$. Foliar sprays were carried out at mid-September before flowering while foliage was still green during 2017 and 2018 seasons. The results indicated that the trees treated with NAA at 75 and $150 \mathrm{mg} \mathrm{l}^{-1}$ gave the same value in delayed blooming (7 days in first season and 5 days in second) as compared with the control treatment. Moreover, Salicylic acid at $150 \mathrm{mg} \mathrm{l}^{-1}$ treatment delayed blooming ( 6 days in first season and 4 days in second). Besides, NAA at $150 \mathrm{mg} \mathrm{l}^{-1}$ enhanced shoot length and number of leaves per shoots. Also, it improved kernel weight. NAA at $150 \mathrm{mg} \mathrm{l}^{-1}$ and salicylic acid at $150 \mathrm{mg}^{-1}$ treatments gave similar and high positive effect on fruit set percentage and yield of "Umm al-Fahm" almond trees. Application of NAA at $150 \mathrm{mg} \mathrm{l}^{-1}$ delay almond blooming moreover, that could be beneficial to avoid frost damage under such conditions. Delayed blooming in almonds under this condition needs more study.
\end{abstract}

Keywords: "Umm al-Fahm" almond tree, late spring frost; bloom delay, NAA; salicylic acid, vegetative growth, productivity

\section{Introduction}

Almond [Prunus dulcis (Miller) D.A. Webb] belongs to the family Rosaceae which is one of the important stone fruits. It became cultivated in Marsa Matrouh Governorate, Egypt, due to the fit climatic conditions. The total area of almond trees in Egypt is about 1733 feddans (one feddan $=0.42 \mathrm{ha}$ ), almond growers in Marsa Matrouh Governorate produced 1027 tons represented $57.40 \%$ of total almond production 1789 tons, according to the statistics of the Ministry of Agriculture, Egypt (2018). Almond trees depend on rain-fed irrigation and sometimes need supplementary irrigation if necessary. Moreover, almond farmers have benefited from the financial return from the sale of the seed crop. Almond cultivated under rain-fed irrigation has not great attention from Egyptian researchers. Although the cultivation of almond along with the cultivation of olives helped and supported farmers to stabilize in this rain-fed coastal area. Almond trees require lower chilling units for flowering in comparison with other temperate fruit trees. The common almond cultivars respond rapidly to short periods of warm temperatures following endodormancy (Denisov, 1988). Frost injury is a major limiting factor in determining commercial production of almond, since buds begin to swell and mature into blooms occurs in the last week of January when frosts are common, they become less resistant to frost injury. Thus, late frost in spring is a key limiting factor for almond productivity given that almond trees flower early in the spring in comparison with other temperate fruit trees (Samani et al., 2006). Thus, a reduction in fruit yield from late spring frost has been a problem in most almond growing regions. Several

Corresponding Author: Amro S.M. Salama, Plant Production Department, Desert Research Center, Cairo, Egypt E-mail: amrosmss@yahoo.com 
horticultural practices could be used to delay bloom and increase yield in almond trees. Growth regulators could be used as one of these horticultural practices. Naphthalene acetic acid (NAA) and Salicylic acid (SA) can be used to delay bloom to avoid frost damage. Delays in bud development reduce the risk of freeze damage by delaying the loss of bud hardiness. Chemical treatments that would delay senescence during the critical autumn hardening period could increase the winter hardiness of flower buds. Plant growth regulators such as NAA and salicylic acid affect leaf senescence and subsequent bud development. Naphthalene acetic acid, commonly abbreviated as NAA is an organic compound, which is a synthetic plant hormone of auxin group and is an ingredient in many commercial horticultural products. Moreover, NAA significantly reduced fruit drop, increased yield, and improved fruit quality. Auxin maintains protein levels and delays senescence in leaves of Prunus and other species (Osborne \& Hallaway, 1960, 1964 and Schuyler et al., 1992). Auxin applications in late summer delay flowering in peach (Hitchcock and Zimmerman, 1943). Moreover, Patterson and Howell (1995) reported that 400 ppm NAA treatment in September delayed "Concord" grapevines bud break. Also, Qrunfleh (2010) found that NAA at $1000 \mathrm{mg} / \mathrm{l}$ treatment significantly delayed bud break 2-6 days as compared with the control of "Edelweiss" grapevines. Salicylic acid (SA) is an endogenous growth regulator of phenolic nature; SA plays a beneficial role during plant response to several abiotic stresses, such as chilling, freezing stresses, heat, drought, salt, and ultraviolet radiation, salicylic acid participates in the regulation of physiological processes in plants (Raskin, 1992; Bergmann et al., 1994 and Van Breusegem et al., 2001). Salicylic acids play a role in plant water relations, photosynthesis, ethylene biosynthesis, stomatal movement, and reversing the effect of ABA on leaf abscission (Arfan et al., 2007). The proposed functions of salicylic acid antagonized the growth inhibitory effect of ABA. Thus it reduces stress-induced inhibition of plant growth (Ding et al., 2001). Furthermore, Noghondar et al., (2013) reported that salicylic acid alleviates the negative effect of cold stress on flower organ damages in apricot. In this respect, Mohammadi et al., (2015) point out salicylic acid at 150 and $300 \mathrm{mg} \mathrm{l}^{-1}$ applied at the swollen bud and green tip stages of peach buds delayed blooming for 3 and 4 days, and it induced positive effects on tree yield and fruit quality parameters.

The objectives of this study were to evaluate the effect of foliar spray of NAA and salicylic acid in delaying bloom and the effect of tested treatments on the vegetative growth, yield and fruit physical quality of "Umm al-Fahm" almond trees.

\section{Material and Methods}

This experiment was conducted during two successive seasons of 2018 and 2019 on almond trees cv. "Umm al-Fahm" grafted onto Bitter almond rootstock. The trees were planted in a private rain-fed almond orchard at northwestern Coast, Marsa Matrouh Governorate, Egypt. Maximum and minimum temperature, the relative humidity, and the amount of rainfall during January, February, and March 2018 and 2019 seasons shown in Table 1, from Central Laboratory for Agriculture Climate, Agricultural Research Center, Egypt.

Table 1: Maximum and minimum temperature, the relative humidity, and the amount of rainfall (2018 and 2019 seasons).

\begin{tabular}{lcccccccc}
\hline & \multicolumn{2}{c}{$\begin{array}{c}\text { Temp. Max. } \\
\left({ }^{\circ} \mathbf{C}\right)\end{array}$} & \multicolumn{2}{c}{$\begin{array}{c}\text { Temp. min. } \\
\left({ }^{\circ} \mathbf{C}\right)\end{array}$} & \multicolumn{2}{c}{ Relative Humidity } & \multicolumn{2}{c}{$\begin{array}{c}\text { Rain total } \\
(\mathbf{\%})\end{array}$} \\
\cline { 2 - 10 } Months & $\mathbf{2 0 1 8}$ & $\mathbf{2 0 1 9}$ & $\mathbf{2 0 1 8}$ & $\mathbf{2 0 1 9}$ & $\mathbf{2 0 1 8}$ & $\mathbf{2 0 1 9}$ & $\mathbf{2 0 1 8}$ & $\mathbf{2 0 1 9}$ \\
\hline January & 18.70 & 17.30 & 10.30 & 7.90 & 65.0 & 53.0 & 24.80 & 10.20 \\
February & 21.50 & 18.30 & 11.90 & 8.60 & 61.0 & 57.0 & 3.20 & 15.80 \\
March & 23.80 & 19.40 & 12.70 & 10.40 & 58.0 & 63.0 & 0.00 & 18.70 \\
Total & 64 & 55 & 34.9 & 26.9 & 184 & 174 & 28 & 44.7 \\
\hline
\end{tabular}

Central Laboratory for Agriculture Climate, Agricultural Research Center, Egypt.

The trees were nine years old at the initiation of the experiment; planted at spacing $7 X 7 \mathrm{~m}$ growing in sandy loam soil texture, with $0.14 \%$ organic matter and $8.7 \mathrm{pH}(1: 2.5)$. Trees were similar in vigor and size. The fertilization program and other horticulture practices were the same for all trees. Twenty trees healthy, nearly uniform in shape and size and productivity and received the same horticulture practices, were subjected to five treatments: 1) control pure water, 2) NAA as foliar sprays at $75 \mathrm{mg} \mathrm{l}^{-1}$, 
3) NAA as foliar sprays at $150 \mathrm{mg} \mathrm{l}^{-1}$, 4) salicylic acid as foliar sprays at $75 \mathrm{mg} \mathrm{l}^{-1}$, 5) salicylic acid as foliar sprays at $150 \mathrm{mg} \mathrm{l}^{-1}$. The tested treatments were conducted in mid-September before flowering while foliage was still green during 2017 and 2018 seasons. Thereupon the treated trees are going to 2018 and 2019 seasons. And the control trees were sprayed with pure water at the previously mentioned time. This study was designed as a randomized complete block design with four replicates for each treatment and each replicate was represented by one tree. The response of almond trees to the tested NAA and salicylic acid treatments was evaluated through the following determinations:

\subsection{Vegetative growth characteristics}

Five uniform shoots were randomly selected on four main branches of each tree and labeled to record Shoot length increase, No. of shoots/branch, and No. of leaves/shoot.

\subsubsection{Shoot length increase (cm), No. of shoots/branch, and No. of leaves/shoot}

In early of both seasons, four branches, nearly uniform in diameter and length were labeled on different treated tree directions. Forty developing vegetative shoots per tree (ten shoots on every branch) were tagged to determine the mean increase in shoot length. The average number of new shoots per branch were counted and recorded. Moreover, leaves of tagged shoots were counted and the increase in their number was determined and recorded.

\subsubsection{Flower bud opening date and Number of delayed days of blooming}

This was recorded when $5-10 \%$ of the terminal buds reached the burst stage. The number of flowering (days) delay relative to control was counted.

\subsection{Tree fruiting parameters}

\subsubsection{Fruit set (\%)}

The number of fruitlets per fluorescence was counted after 3 weeks of full bloom to determine the initial number of set fruitlets. The initial fruit set was calculated as a percentage.

\subsubsection{Yield kg/tree}

In each season, at the harvest time first week of July, yield ( $\mathrm{kg} /$ tree) was weighed and recorded.

\subsection{Fruit quality parameters}

Twenty ripen fruits were taken at harvest when the almonds were found to be ripe, at least $80 \%$ open hull from each treated tree. The fruit separated to obtain the almond kernels then the determination of the following physical properties i.e. kernel weight (g), inshell (\%), kernel length $(\mathrm{cm})$, and kernel width $(\mathrm{cm})$.

\subsection{Statistical analysis}

The obtained data in 2018 and 2019 seasons were subjected to analysis of variance according to Clarke and Kempson (1997). Means were differentiated using the Range test at the 0.05 level (Duncan, 1955)

\section{Results and Discussion}

\subsection{Vegetative growth characteristics}

\subsubsection{Shoot length increase $(\mathbf{c m})$}

Table, 2 demonstrates that in the first season NAA at $150 \mathrm{mg}^{-1}$ treatment gave a high positive effect on shoot length as compared with the control treatment. However, NAA at $150 \mathrm{mg} \mathrm{l}^{-1}$ also, salicylic acid at 75 and $150 \mathrm{mg} \mathrm{l}^{-1}$ treatments produced a similar and high positive effect on shoot length as compared with the control treatment in the second season in this study.

\subsubsection{No. of shoots/branch}

Table, 2 mentions that all NAA and salicylic acid treatments gave a similar and higher significant effect on the number of shoots than the control treatment in the both seasons. 


\subsubsection{No. of leaves/shoot}

Table, 2 indicates that NAA at 75 or $150 \mathrm{mg} \mathrm{l}^{-1}$ and salicylic acid at $150 \mathrm{mg} \mathrm{l}^{-1}$ treatments produced a similar positive effect on the number of leaves/shoot as compared with the control treatment in the first season. However, NAA at both concentrations and salicylic acid at $150 \mathrm{mg} \mathrm{l}^{-1}$ concentration gave a high positive effect on the number of leaves/shoot as compared with the control treatment in the second season.

Table 2: Effect of NAA and salicylic acid foliar sprays on shoot length, number of shoots, and number of leaves/shoot of Almond trees during 2018 and 2019 seasons.

\begin{tabular}{lcccccc}
\hline Treatments & \multicolumn{2}{c}{ Shoot length (cm) } & \multicolumn{2}{c}{ Number of shoots } & \multicolumn{2}{c}{ Number of leaves/shoot } \\
\cline { 2 - 7 } Conc. mg I I $^{-\mathbf{1}}$ & $\mathbf{2 0 1 8}$ & $\mathbf{2 0 1 9}$ & $\mathbf{2 0 1 8}$ & $\mathbf{2 0 1 9}$ & $\mathbf{2 0 1 8}$ & $\mathbf{2 0 1 9}$ \\
\hline Control & $30.0 \mathrm{D}$ & $29.0 \mathrm{~B}$ & $12 \mathrm{~B}$ & $9 \mathrm{~B}$ & $16 \mathrm{~B}$ & $13 \mathrm{C}$ \\
75 NAA & $37.0 \mathrm{BC}$ & $35.0 \mathrm{AB}$ & $17 \mathrm{~A}$ & $13 \mathrm{~A}$ & $22 \mathrm{~A}$ & $19 \mathrm{AB}$ \\
150 NAA & $42.6 \mathrm{~A}$ & $41.0 \mathrm{~A}$ & $18 \mathrm{~A}$ & $14 \mathrm{~A}$ & $25 \mathrm{~A}$ & $23 \mathrm{~A}$ \\
75 SA & $36.0 \mathrm{C}$ & $36.0 \mathrm{~A}$ & $14 \mathrm{AB}$ & $12 \mathrm{~A}$ & $20 \mathrm{~B}$ & $17 \mathrm{BC}$ \\
$\mathbf{1 5 0} \mathbf{~ S A}$ & $41.0 \mathrm{AB}$ & $41.0 \mathrm{~A}$ & $16 \mathrm{AB}$ & $13 \mathrm{~A}$ & $25 \mathrm{~A}$ & $20 \mathrm{AB}$ \\
\hline
\end{tabular}

Means followed by the same letter (s) within each column are not significantly different at $5 \%$ level.

The enhancement effect of NAA on vegetative growth might be attributed to the stimulation of vegetative growth that leads to an increasing in shoot length, the number of shoots, and the number of leaves/shoot. NAA are important growth regulators for the plant, since they are playing an important role in cell division and cell wall elongation and leads to increase shoot length (Crosier et al., 2000). The obtained results regarding the effect of NAA on vegetative growth are in harmony with the findings of Hifny et al., (2017).They mentioned that NAA treatment enhanced the vegetative growth of orange trees. The effect of salicylic acid on vegetative growth may be attributed that salicylic acid is a growth regulator that participates in the regulation of physiological processes in plants. Salicylic acid plays a beneficial role during plant response to several abiotic stresses, such as chilling and freezing stresses. Salicylic acid participates in the regulation of physiological processes in plants (Raskin, 1992; Bergmann et al., 1994 \& Van Breusegem et al., 2001). Salicylic acid showed a synergetic effect like auxin and gibberellins (Sanaa et al., 2006). Salicylic acids have a direct effect on plant growth and ions uptake (Romani et al., 1989). It was found also to accelerate the photosynthetic rate, modify the activity of important enzymes, increase the leaf area and dry mass production, and exhibit a rapid rate of root differentiation, (Hayat and Ahmed, 2007). That reflected on enhanced vegetative growth. The obtained results regarding the effect of salicylic acid on vegetative growth are in harmony with the findings of Abd El- Aziz et al., (2017) on pomegranate.

\subsection{Flower bud opening date and Number of delayed days of blooming \\ 3.2.1. Flower bud opening date}

Table, 3 indicates that all the treatments at all concentrations affected on the date of the beginning of flowering. Furthermore, NAA at 75 and $150 \mathrm{mg} \mathrm{l}^{-1}$ recorded the same date of flower bud opening on (Feb., $\left.2^{\text {nd }}\right)$ in the first season and (Jan., $\left.28^{\text {th }}\right)$ in the second season, as compared with control (Jan., $26^{\text {th }}$ and Jan., $23^{\text {th }}$ ) in both seasons, respectively. Salicylic acid at $150 \mathrm{mg}^{-1}$ treatment records the date bud opening on (Feb., $1^{\text {st }}$ and Jan., $27^{\text {th }}$ ) in both seasons, respectively. NAA at $75 \mathrm{mg} \mathrm{l}^{-1}$ and $150 \mathrm{mg} \mathrm{l}^{-1}$ treatments showed superiority in retarding the blooming date.

Table 3: Effect of NAA and salicylic acid foliar sprays on flower delay of Almond trees during 2018 and 2019 seasons.

\begin{tabular}{|c|c|c|c|c|}
\hline \multirow{2}{*}{$\begin{array}{l}\text { Treatments } \\
\text { Conc. mg l }{ }^{-1}\end{array}$} & \multicolumn{2}{|c|}{ Date of flower bud opening } & \multicolumn{2}{|c|}{$\begin{array}{c}\text { Number of delaying days of begging } \\
\text { flower }\end{array}$} \\
\hline & 2018 & 2019 & 2018 & 2019 \\
\hline Control & 26- Jan & 23-Jan & $0 \mathrm{C}$ & $0 \mathrm{C}$ \\
\hline 75 NAA & 2- Feb & 28- Jan & $7 \mathrm{~A}$ & $5 \mathrm{~A}$ \\
\hline 150 NAA & 2- Feb & 28-Jan & $7 \mathrm{~A}$ & $5 \mathrm{~A}$ \\
\hline $75 \mathrm{SA}$ & 30- Jan & 26- Jan & $4 \mathrm{~B}$ & $3 \mathrm{~B}$ \\
\hline $150 \mathrm{SA}$ & $1-$ Feb & 27- Jan & $6 \mathrm{~A}$ & $4 \mathrm{AB}$ \\
\hline
\end{tabular}

Means followed by the same letter (s) within each column are not significantly different at $5 \%$ level. 


\subsubsection{A number of delayed days of blooming}

Table, 3 shows that all tested NAA and salicylic acid treatments retarded blooming date as compared with the control (the basic comparison) in both seasons. Generally, NAA treatments surpassed salicylic acid treatments in delayed blooming days. Briefly, NAA spray at 75 and $150 \mathrm{mg} \mathrm{l}^{-1}$ treatments gave the same value in delayed blooming ( 7 days in the first season and 5 days in the second season) as compared with the control. Furthermore, NAA at two concentrations showed superiority in retarding the blooming date.

The enhancement effect of NAA on delayed blooming may be attributed that Auxin applications in late summer delay flowering in peach (Hitchcock and Zimmerman, 1943). The obtained results regarding the effect of NAA on delayed blooming go in line with the findings of Patterson and Howell (1995) they mentioned that 400 ppm NAA treatment in September delayed "Concord" bud break. In addition, Qrunfleh (2010) found that NAA at $1000 \mathrm{mg} / 1$ significantly delayed bud break 2-6 days as compared with the control. The effect of salicylic acid on delayed blooming may be attributed that salicylic acid application, perhaps the accumulation of ABA in peach, might have caused a reduction of growth buds and created bloom delay (Raskin, 1992). The obtained results regarding the effect of salicylic acid on delayed blooming go in line with the findings of Noghondar et al., (2013) on apricot and Mohammadi et al., (2015) on peach. They indicated that the salicylic acid application delayed the blooming of the aforementioned fruit species.

\subsection{Tree fruiting parameters}

\subsubsection{Fruit set $(\%)$}

Table, 4 demonstrates that all tested NAA and salicylic acid treatments produced a statistically similar and higher positive effects on fruit set percentage of almond trees as compared with control treatment in both seasons. Anyhow, $150 \mathrm{mg}^{-1} \mathrm{NAA}$ and $150 \mathrm{mg} \mathrm{l}^{-1}$ salicylic acid treatments showed superiority in this respect. Other concentrations gave intermediate values in this respect.

Table 4: Effect of NAA and salicylic acid foliar sprays on fruit set percentage and yield of Almond trees during 2018 and 2019 seasons.

\begin{tabular}{lcccc}
\hline Treatments & \multicolumn{2}{c}{ Fruit set (\%) } & \multicolumn{2}{c}{ Yield (Kg/tree) } \\
\cline { 2 - 5 } Conc. mg I $^{\mathbf{1}}$ & $\mathbf{2 0 1 8}$ & $\mathbf{2 0 1 9}$ & $\mathbf{2 0 1 8}$ & $\mathbf{2 0 1 9}$ \\
\hline Control & $21.52 \mathrm{C}$ & $22.76 \mathrm{C}$ & $3.81 \mathrm{C}$ & $4.07 \mathrm{C}$ \\
75 NAA & $24.17 \mathrm{~B}$ & $27.61 \mathrm{AB}$ & $4.27 \mathrm{AB}$ & $4.62 \mathrm{~B}$ \\
150 NAA & $31.56 \mathrm{~A}$ & $32.15 \mathrm{~A}$ & $4.80 \mathrm{~A}$ & $5.47 \mathrm{~A}$ \\
75 SA & $23.74 \mathrm{~B}$ & $26.03 \mathrm{AB}$ & $4.03 \mathrm{~B}$ & $4.51 \mathrm{BC}$ \\
150 SA & $28.77 \mathrm{~A}$ & $31.72 \mathrm{~A}$ & $4.69 \mathrm{~A}$ & $5.36 \mathrm{~A}$ \\
\hline
\end{tabular}

Means followed by the same letter (s) within each column are not significantly different at $5 \%$ level.

\subsubsection{Yield ( $\mathrm{kg} /$ tree)}

Table, 4 illustrates that all tested treatments except salicylic acid at $75 \mathrm{mg} / \mathrm{L}^{-1}$ at second season induced a high positive effect on yield as compared with the control treatment in both seasons. Generally, $150 \mathrm{mg} \mathrm{l}^{-1} \mathrm{NAA}$ and $150 \mathrm{mg} \mathrm{l}^{-1}$ salicylic acid treatments proved to be the superior treatments as compared with control in both seasons. Other treatments gave intermediate values in this respect.

\subsection{Fruit quality parameters}

\subsubsection{Kernel weight (g)}

Table, 5 illustrates that the tested NAA and salicylic acid treatments exerted a positive improving effect on the kernel weight of almond trees as compared with the control in both seasons. Generally, NAA acid at $150 \mathrm{mg} \mathrm{l}^{-1}$ produced high values of fruit kernel weight in both seasons. Other treatments gave intermediate value in concern.

\subsubsection{Inshell (\%)}

Table, 5 demonstrates that NAA and salicylic acid treatments produced statistically similar effects on the inshell percentage of Almond fruits as compared with the control in the first season. In the second season, all tested treatments had no significant effect on the inshell percentage of Almond trees. 
Table 5: Effect of NAA and salicylic acid foliar sprays on fruit kernel weight and fruit inshell percentage of Almond trees during 2018 and 2019 seasons.

\begin{tabular}{lcccc}
\hline Treatments & \multicolumn{2}{c}{ Kernel weight (g) } & \multicolumn{2}{c}{ Inshell (\%) } \\
\cline { 2 - 5 } Conc. mg l $\mathbf{1}^{\mathbf{1}}$ & $\mathbf{2 0 1 8}$ & $\mathbf{2 0 1 9}$ & $\mathbf{2 0 1 8}$ & $\mathbf{2 0 1 9}$ \\
\hline Control & $1.18 \mathrm{C}$ & $1.20 \mathrm{C}$ & $63.25 \mathrm{~B}$ & $70.32 \mathrm{~A}$ \\
75 NAA & $1.25 \mathrm{AB}$ & $1.30 \mathrm{AB}$ & $67.93 \mathrm{~A}$ & $71.61 \mathrm{~A}$ \\
150 NAA & $1.28 \mathrm{~A}$ & $1.33 \mathrm{~A}$ & $69.51 \mathrm{~A}$ & $71.87 \mathrm{~A}$ \\
$\mathbf{7 5}$ SA & $1.23 \mathrm{~B}$ & $1.25 \mathrm{BC}$ & $70.32 \mathrm{~A}$ & $72.77 \mathrm{~A}$ \\
$\mathbf{1 5 0}$ SA & $1.26 \mathrm{AB}$ & $1.26 \mathrm{~B}$ & $70.97 \mathrm{~A}$ & $72.96 \mathrm{~A}$ \\
\hline
\end{tabular}

Means followed by the same letter (s) within each column is not significantly different at $5 \%$ level.

\subsubsection{Kernel length $(\mathrm{mm})$}

Table, 6 illustrates that the tested concentrations $\left(75\right.$ and $\left.150 \mathrm{mg} \mathrm{l}^{-1}\right)$ of NAA or salicylic acid treatments exerted a positive enhancing effect on kernel length of almond trees as compared with the control in the first seasons moreover, $150 \mathrm{mg} \mathrm{l}^{-1}$ of NAA showed superiority in this respect. In the second season NAA, salicylic acid, and control treatments had no significant effect on fruit kernel length of Almond trees.

Table 6: Effect of NAA and salicylic acid foliar sprays on fruit kernel length and width of Almond trees during 2018 and 2019seasons.

\begin{tabular}{lcccc}
\hline Treatments & \multicolumn{2}{c}{ Kernel length $(\mathbf{m m})$} & \multicolumn{2}{c}{ Kernel width $\mathbf{( m m})$} \\
\cline { 2 - 5 }${\text { Conc. } \text { mg I }^{\mathbf{1}}}^{\mathbf{1}}$ & $\mathbf{2 0 1 8}$ & $\mathbf{2 0 1 9}$ & $\mathbf{2 0 1 8}$ & $\mathbf{2 0 1 9}$ \\
\hline Control & $14.88 \mathrm{C}$ & $13.36 \mathrm{~A}$ & $3.59 \mathrm{~A}$ & $3.16 \mathrm{C}$ \\
75 NAA & $16.05 \mathrm{BC}$ & $16.85 \mathrm{~A}$ & $3.78 \mathrm{~A}$ & $3.28 \mathrm{BC}$ \\
150 NAA & $18.85 \mathrm{~A}$ & $17.30 \mathrm{~A}$ & $3.97 \mathrm{~A}$ & $3.80 \mathrm{~A}$ \\
75 SA & $17.88 \mathrm{AB}$ & $16.49 \mathrm{~A}$ & $3.54 \mathrm{~A}$ & $3.65 \mathrm{AB}$ \\
150 SA & $18.40 \mathrm{AB}$ & $17.18 \mathrm{~A}$ & $3.91 \mathrm{~A}$ & $3.79 \mathrm{~A}$ \\
\hline
\end{tabular}

Means followed by the same letter (s) within each column is not significantly different at $5 \%$ level.

\subsubsection{Kernel width (mm)}

Table, 6 indicates that all treatments had no significant effect on kernel width in the first season. Generally, $150 \mathrm{mg} \mathrm{l}^{-1} \mathrm{NAA}$ or $150 \mathrm{mg} \mathrm{l}^{-1}$ salicylic acid treatments proved to be the superior treatments as compared with control in the second season.

The enhancement effect of NAA on fruit set, yield, and some fruit properties may be attributed that firstly, the promotion effect of NAA on improving growth characteristics. Secondly, it delayed blooming, and it avoiding frost damage that reflected on good flowering, fruit set, and productivity. Thirdly, NAA plays an important role in increased the mobilization of food and minerals from other parts of the plant towards developing fruits and this reflected in increasing weight and volume (Arora and Singh, 2014). So that increased yield and improved fruit quality. The obtained results regarding the effect of NAA on fruit set, yield and some fruit properties go in line with the findings of Abd El-Naby et al., (2019) on apricot; Agrawal and Dikshit (2008) on sapota trees and by Nkansah et al., (2012) on mangoes trees. The enhancement effect of salicylic acid foliar spray on fruit set, yield, and some fruit properties may be attributed that the salicylic acid plays a vital role in plant growth, and ion uptake and transport (Hayat et al., 2010). Salicylic acid can also play a role in plant water relations, photosynthesis, and ethylene biosynthesis (Arfan et al., 2007). It enhanced the activities of antioxidant enzymes to the drought and salinity stress in plants (Hayat et al., 2008 and Yusuf et al., 2008). Furthermore, salicylic acid increased the leaf chlorophyll content (Abd El- Aziz et al., 2017). These lead to more carbohydrate production reflected in increasing fruit set percentage and consequently improved fruit set. Thus, it enhanced yield and kernel weight. Although in this research trees treated with salicylic acid escaped from frost damage. The obtained results regarding the effect of salicylic acid on fruit set, yield and some fruit properties go in line with the findings of Mohammadi et al., (2015) on peach. Moreover, Khedr (2018) on pear and Abd El-Razek et al., (2013) on olive trees.

The results mentioned that NAA or salicylic acid at 75 and $150 \mathrm{mg} \mathrm{l}^{-1}$ applied on September $15^{\text {th }}$ can be recommended to delay bloom in almond under this condition. NAA or salicylic acid at $150 \mathrm{mg}$ $1^{-1}$ treatments enhanced tree growth, yield, and fruit physical traits. 


\section{Reference}

Abd El-Aziz, F.H., M.A. El-Sayed, and H.A. Aly, 2017. Response of Manfalouty pomegranate trees to foliar application of salicylic acid, Assiut, J. Agric. Sci., 48 (2) : 59-74.

Abd El-Naby, S.K.M., A.A.A. Mohamed, and Y.I.M. El-Naggar, 2019. Effect of meatonin, GA3 and NAA on vegetative growth, yield of 'Canino; apricot fruits. Acta Sci., Pol. Hortorum Cultus, 18(3):167-174.

Abd El-Razek, E., H.S.A. Hassan, and K.M. Gamal El- Din, 2013. Effect of foliar application with salicylic acid, benzyladenine and gibberellic acid on flowering, yield and fruit quality of olive trees (Olea europaea L.). Middle-East Journal of Scientific Research, 14 (11): 1401-1406.

Agrawal, S. and S.N. Dikshit, 2008. Studies on the effect of plant growth regulators on growth and yield of sapota (Achras sapota L.) cv. Crikest ball. Indiana J. Agric. Res., 42:207-2011.

Agriculture statistics, Ministry of Agriculture, Economic Affairs Sector, Egypt, 2018.

Arfan, M., H.R. Athar, and M. Ashraf, 2007. Does exogenous application of salicylic acid through the rooting medium modulate growth and photosynthetic capacity in two differently adapted spring wheat cultivars under salt stress? J. Plan. Physiol., 6 (4): 685-694.

Arora, R. and S. Singh, 2014. Effect of growth regulators on quality of Ber (Zizyphus mauritiana Lamk) cv. 'Umran'. Agric. Sci. Digest., 34(2): 102-106.

Bergmann, H.L., V. Maachelett, and B. Gerbel, 1994. Increase of stress resistance in crop plants by using phenolic compounds. Acta. Hort., 381:390-395.

Clarke, G.M. and R.E. Kempson, 1997. Introduction to the design and analysis of experiments. Arnold, a Member of the Holder Headline Group, 1st Edt. London, UK.

Crosier, A., Y. Kamiya, G. Bishop, and Y. Yokota, 2000. Biosynthesis of hormones and Selicitor molecules. In: "Biochemistry and Molecular Biology of Plants", B.B. Buchanan, W. Gruissem and R.L. Jones (Ed.), pp. 850-901, Rockville, USA: American Society of Plant Physioloits.

Denisov, V.P., 1988. Almond genetic resources in the USSR and their uses in production and breeding. Acta Hort., 224:299-306.

Ding, C. K., C.Y. Wang, K.C. Gross, and D.L. Smith, 2001. Reduction of Chilling Injury and Transcript Accumulation of Heat Shock Proteins in Tomato Fruit by Methyl Jasmonate and Methyl Salicylate. Plant. Sci., 161:1153-1159.

Duncan, D.B., 1955. Multiple ranges and multiple F Test. Biometrics, 11: 1-42.

Hayat, S. and A. Ahmad., 2007. Salicylic Acid: a Plant Hormone. Springer, 401.

Hayat, S., Hasan, S.A., Q. Fariduddin, and A. Ahmad, 2008. Growth of tomato (Lycopersicone sculentum) in response to salicylic acid under water stress. J. Plant Interact, 3: 297-304.

Hayat, Q., S. Hayat, M. Irfan, and A. Ahmad, 2010. Effect of exogenous salicylic acid under changing environment: A review. Environmental and Experimental Botany, 68: 14-25.

Hifny, H.A., S.M. Khalifa, A.E. Hamdy, and A.N. Abd El-Wahed, 2017. Effect of GA 3 and NAA on growth, yield and fruit quality of washington navel orange. Egypt. J. Hort., 44(1): 33- 43.

Hitchcock, A.E. and P.W. Zimmerman., 1943. Summer sprays with potassium a-naphthalene acetate retard opening of buds on fruit trees. Proc. Amer. Soc. Hort. Sci., 42:141-145.

Khedr, E.H., 2018. Improving productivity, quality and antioxidant capacity of Le-Conte pear fruits using foliar tryptophan, arginine and salicylic applications. Egypt J. Hort. 45(1): 93 - 103.

Mohammadi, H., P. Zahra, and S. Vahidreza, 2015. Role of methyl jasmonate and salicylic acid applications on bloom delay, flowering and fruiting of 'Elberta' Peach. Int. J. Hort. Sci. Technol, 2(1): 75-85

Nkansah, G.O., J. Ofosu-Anim, and A. Mawuli, 2012. Gibberellinc acid and naphthalene acetic acid affect fruit retention, yield and quality of keitt mangoes in the Coastal Savana ecogical zone of Ghana. American Journal of plant physiology, 7(6):243-251.

Noghondar, A.M., H. Bayat, and H. Neamati, 2013. Effect of Salicylic Acid on Alleviating of Electrolyte Leakage and Flower Organ Damage in Apricot (Prunus armeniaca L. cv. 'Shahroudi') under Artificial Cold Stress. Not Sci Biol, 5(1):62-66.

Osborne, D.J. and H.M. Hallaway, 1960. Auxin control of protein levels in detached autumn leaves. Nature (London) 188:240-241.

Osborne, D.J. and H.M. Hallaway, 1964. The auxin 2, 4-D as a regulator of protein synthesis and senescence in detached leaves of Prunus. New Phytol., 63:334-336. 
Patterson, W. and D. Howell, 1995. Effect of fall-applied plant growth regulating compounds on bud break of "Concord"e and „Riesling". American Journal of Enology \& Viticulture, 46 (3): 414.

Qrunfleh, I.M., 2010. Delaying bud break in 'Edelweiss' grapevines to avoid spring frost injury by NAA and vegetable oil applications. The Graduate College at the University of Nebraska. Lincoln, Nebraska.

Raskin, I., 1992. Role of salicylic acid in plants. Annual Review Plant Physiology, 43: 439-463.

Romani, R. H., V.M. Hess, and C.A. Lestic, 1989. Salicylic acid inhibition of ethylene production by apple discs and other plant tissues. J. Plant Growth Regulators, 8: 62-69.

Samani, R.B., M. Mostafavi, A. Khalighi, and A. Mousavi, 2006. Effect of different amounts and application times of soybean oil on delaying time blooming of almond. Acta, Hortic. 726: 471474.

Sanaa, A. M., M.A. Mostafa, and S.A.M. Shehata, 2006. Physiological studies on the effect of kinetin and salicylic acid on growth and yield of wheat plant. Annals Agric. Sci., Ain Shams Univ., Cairo, 51(1): 41-55.

Schuyler, D.S., H. Damavandy, and J.L. Anderson, 1992. Autumn-applied growth regulators influence leaf retention, bud hardiness, bud and flower size, and endodormancy in peach and cherry. J. AMER. Soc. HORT. SCI., 117(2):203-208.

Van Breusegem, F., E. Vraneva and J.F. Dat, 2001. The role of active oxygen species in plant signal transduction. Plant Sci., 161:405-414.

Yusuf, M., S.A. Hasan, B. Ali, S. Hayat, Q. Fariduddin, and A. Ahmad, 2008. Effect of salicylic acid on salinity induced changes in Brassica juncea. Journal of Integrative Plant Biology, 50: 1-4. 